\title{
Erratum
}

Genes \& Development 11: 1748-1758 (1997)

Jun in D rosophila development: redundant and nonredundant functions and regulation by two MAPK signal transduction pathways

Lutz Kockel, Julia Zeitlinger, Lena M. Staszewski, Marek Mlodzik, and Dirk Bohmann

A reported defect of photoreceoptor differentiation in flies heterzygous for both Drosophila jun and Drosophila ERK (rolled) null alleles reported in the above paper has proven to be irreproducible, and the basis for the published effect that was observed in two independent experiments is unclear. Though this piece of evidence must be disregarded, the remaining experiments presented in the paper have been reproduced and remain valid. The authors apologize for the unintentional misinformation and thank Dr. Ernst Hafen for pointing out experimental discrepancies. 


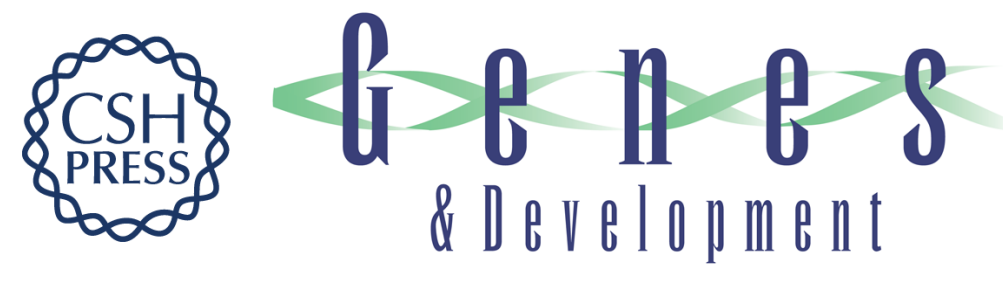

\section{Errata for vol. 11, p. 1748}

Genes Dev. 1998, 12:

\section{License}

Email Alerting Receive free email alerts when new articles cite this article - sign up in the box at the top Service right corner of the article or click here.

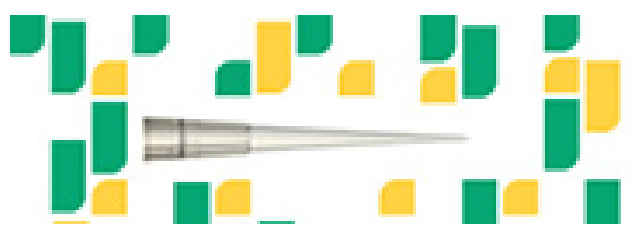

Focused on your science. 